\title{
Greenland ice-sheet mass-balance distribution: a variance analysis of existing field data
}

\author{
Delphine Six, ${ }^{1}$ Anne Letréguilly, ${ }^{1,2}$ Louis Reynaud ${ }^{1,2}$ \\ ${ }^{1}$ Laboratoire de Glaciologie et Géophysique de l'Environnement du CNRS, 54 rue Molière, BP 96, 38402 Saint-Martin-d'Hères Cedex, France \\ ${ }^{2}$ Université Joseph Fourier ( Grenoble 1), 38402 Saint-Martin-d'Hères Cedex, France
}

\begin{abstract}
A large number of mass-balance measurements have been carried out on the Greenland ice sheet, but few of the series obtained are well suited for statistical studies. Rather than looking at the global mass-balance value, this paper deals with the spatial and temporal mass-balance variability on the ice sheet. Two sorts of analysis are possible: direct comparisons of the series measured at a given site, or a broader approach involving comparisons between different sites using variance analysis. For glaciers in the southwest ablation area, a significant interannual variability (around $1.0 \mathrm{~m}$ w.e.) is found. This variability is spatially consistent. In the accumulation area, the results are more complex. For example, there is consistent evidence of year-to-year variations on the west-east Expéditions Glaciologiques Internationales au Groenland (EGIG) profile, but other closer sites are weakly correlated. These results emphasize the need for a better coverage of measurements over the entire ice sheet, as well as longer and more continuous measurement series.
\end{abstract}

\section{INTRODUGTION}

The contribution of ice masses to variations in sea level is an important issue. One way of addressing the problem is to measure the mass balance of the ice masses, in order to gain some insight into their mass variations. In Greenland, many mass-balance measurements have been performed over the last 100 years. These data have been compiled by a number of investigators, usually for the purpose of mapping accumulation distribution over the ice sheet or to estimate the global mass balance (e.g. Loewe, 1936; Bauer, 1955; Diamond, 1960; Benson, 1962; Mock, 1967; Ohmura and Reeh, 1991; Oerlemans and others, 1993; Ohmura and others, 1999). However, the spatial distribution of the measurements, as well as the periods covered, do not reflect a regular network, and the questions of temporal variability of the mass balance and of spatial representativeness of measurement sites have not yet been dealt with to any great extent. On other glaciers where such studies have been carried out, the different measurement sites are often spatially consistent (up to distances of around $500 \mathrm{~km}$ ), but the mass balance has been shown to be highly variable from year to year (Reynaud and others, 1984; Letréguilly and Reynaud, 1990).

In order to produce a reliable estimate of the global mass balance by means of ground surveys (one that could be used to evaluate Greenland's contribution to sea-level variations), the representativeness of the measurements must be investigated in detail. In this work, we focus on the available measurements and, rather than try to produce a new global mass-balance value that would be little better than previous ones, we try to identify variations in patterns of spatial and temporal mass-balance distributions. By means of massbalance data comparisons, the aim of this work is to indicate what degree of confidence can be placed in any Greenland global mass-balance value.

\section{MASS-BALANGE DATA}

Many past mass-balance surveys in Greenland are reported in the literature (Weidick, 1968; Reeh, 1989; Braithwaite, 1996). For the present work, we collected all the published annual mass-balance data we could find in the literature, together with unpublished measurements such as those made by Expéditions Polaires Françaises (Pourchet, 1970). Altogether, our bibliographical search yielded about 250 different measurement sites. The datasets are inhomogeneous in many respects:

There is a large variety in the location of measurement sites: on the accumulation area, on the edge of the ablation area or on some isolated ice caps of the continent.

The measurement sites are unequally distributed: some areas are well covered (e.g. the centre or the southwest coast) while others seem to have been forgotten (e.g. the southeastern part of the ice sheet).

The lengths of the measurement periods are very different from one site to another. Most often, annual massbalance series are short, in some cases limited to a single mass-balance measurement. In the ablation zone (essentially studied for hydropower use), where balances can be obtained only by means of repeated annual visits, series are all < 10 years. Furthermore, series are not synchronous: there is not a single year with massbalance measurements on all sites or even half the sites.

In the accumulation area, measurement methods differ (radioactivity, chemistry, dust content, ${ }^{18} \mathrm{O}$ variations). Some series record snow heights or $\delta^{18} \mathrm{O}$ values, without density measurements (e.g. Dye 2 and Camp Century, both in 1977).

The values of mass-balance series are not always annual: 


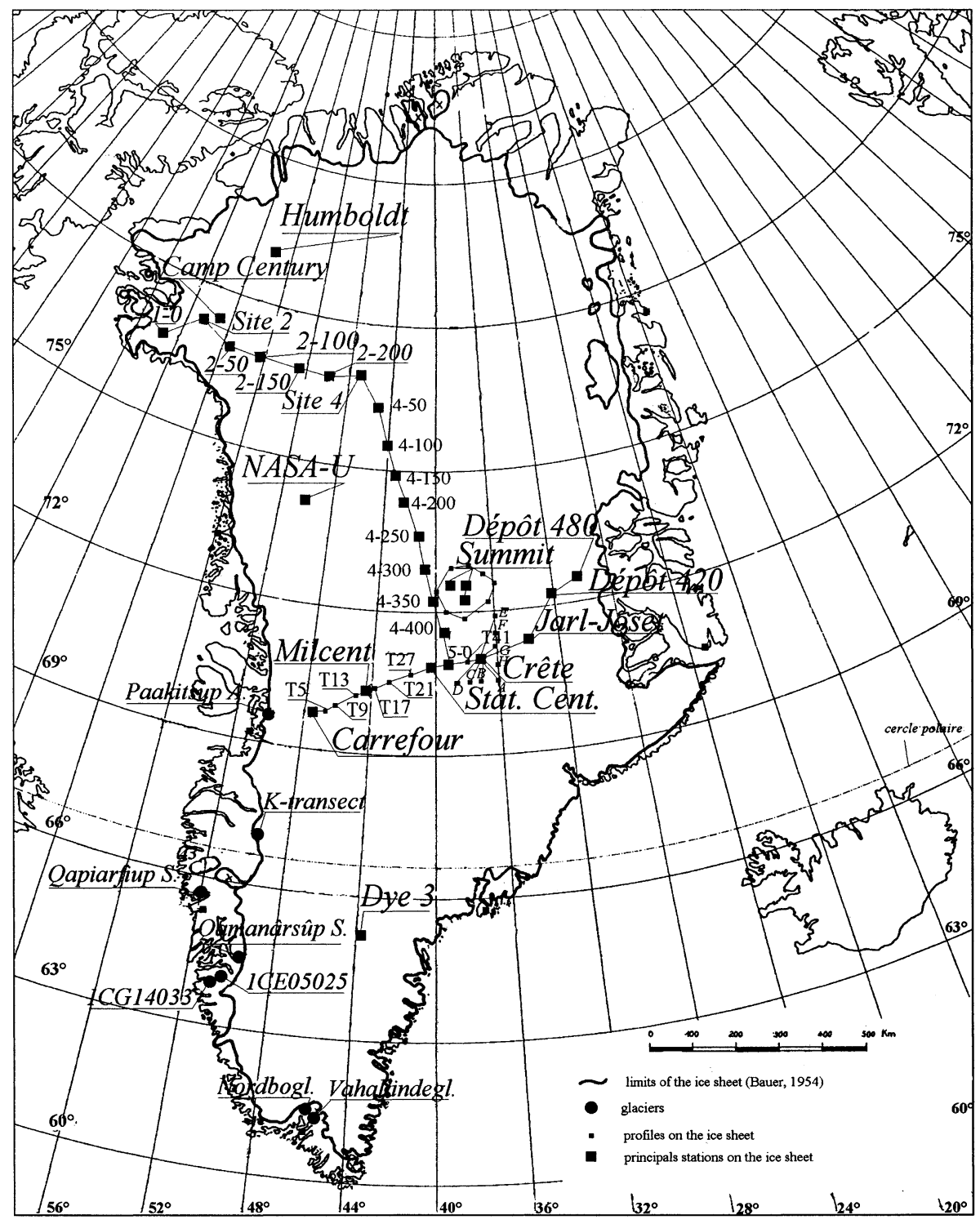

Fig. 1. Map of mass-balance sites on the Greenland ice sheet for series longer than 5 years. The outlines are from Bauer (1955) and the map (1:5000 000) from the Geodetisk Institut, Copenhagen. The names of the glaciers, the names of the principal stations and the different profiles studied on the ice sheet are shown.

when data are extracted from ice cores, some series consist of multi-annual values (values averaged over several years) or inversely of sub-annual values (the ice core is analyzed on regular sections that do not match the annual cycles (e.g. Greenland Icecore Project (GRIP) ice core (Hammer and others, 1997)).

For some of the oldest measurements, the use of nonstandard terms obscures the meaning of what was obtained (e.g. "ablation value" was used to mean "massbalance value" in the ablation zone).

For some expeditions, only graphs of accumulation could be found (e.g. Benson, 1962), and not the actual series of values. However, these graphs are often of interest because the series cover a period and an area otherwise little explored.

In order to compare the space and time variations of the different parts of the Greenland ice sheet, data should have a comparable basis (e.g. the series should be expressed as annual values and in water equivalent). Hence, multi- or sub-annual values, and those without density information, were excluded. Furthermore, if a reliable statistical analysis is to be made, only long series should be kept (generally speaking, $>15$ years for statistically significant tests). However, keeping only such series would eliminate all the series in the ablation zone, as well as many in the accumulation area. We therefore set the limit in the database, for our spatio-temporal patterns search, to a minimum of 5 years. Furthermore, only series occurring within the last century are considered, in order to allow comparisons with series from other studies performed in other regions of the world, where field measurements go back only 100 years.

All these criteria reduced the initial 250 data-collection sites to about 60 sites which could be analyzed. The selected sites are shown on the map in Figure 1. Three main geographical areas were distinguished: the south (individual coastal glaciers, the inland ice margin, Dye 3 station), the centre (the east-west profile Expéditions Glaciologiques Internationales au Groenland (EGIG) line, Summit and surrounding sites) and the north (Benson's profile and the ice cores of Site 2, Camp Century, NASA-U and Humboldt).

Figure 2 shows the temporal coverage of these stations and the different types of measurements carried out in the three geographical areas. Obviously, this dataset is very sparse, and our analysis will take this into account. 


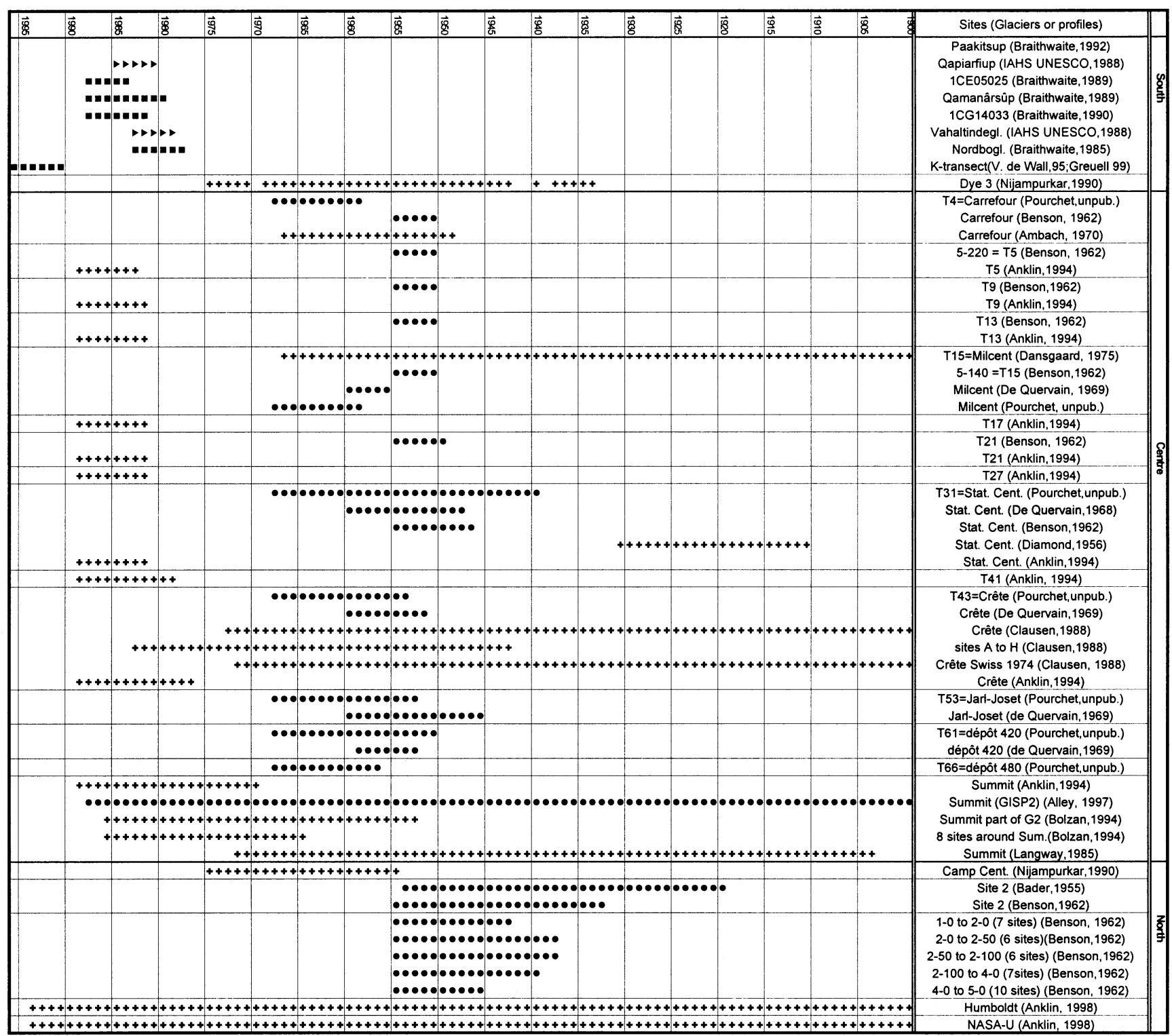

Fig. 2. Summary of data analyzed in this study. The vertical axis is the date, and the horizontal axis the different sites in the three regions ( south, centre and north), with the sources of the data. For brevity, only the first author of each publication is given. The different symbols represent the different measurement methods: - group of ablation stakes; $\mathbf{\Delta}$ global balance of isolated glaciers; deviation from the mean of a group of ablation stakes; • ice cores or pits, annual layers determined by stratigraphy; $\mathbf{+}$ ice cores or pits, annual layers determined by seasonal tracers (isotopy).

\section{DATA-ANALYSIS METHODS}

The search for spatial and temporal mass-balance patterns required analysis methods developed at several different scales. Local analysis of each site was first necessary to establish a unique series (based on the different series performed at each site) which could be compared later to other sites in a large-scale analysis.

\subsection{Local-scale methods}

In the accumulation zone, repeated drillings at more or less the same site by different authors sometimes lead to two or three values (or more) for the same year (e.g. Station Centrale (1948-55) or Carrefour (1959-67); see Fig. 2). In such cases, the first analytical step was a direct comparison of the mass-balance values from the common period, in the hope of establishing (or choosing) a unique representative series for each site, or obtaining series spanning a longer period.

In the ablation area, sites are often outlet glaciers of the inland ice sheet where measurements were made annually at different stakes on the glacier. Unfortunately, the mass-balance datasets vs time and altitude were often incomplete and the glacier surface areas were never precisely determined. Therefore, the global annual mass balance of the entire glacier could not be determined by means of the glaciological method. In order to establish a unique temporal series for the glacier, the first analytical step was to compare mass-balance values at the different stakes on each glacier. This local comparison allowed us to determine if a linear variation could be assumed at the glacier scale. If yes, the mass-balance datasets vs time and altitude for each glacier could be reduced to a unique series using Lliboutry's algorithm (Lliboutry, 1974). This algorithm is based on observed characteristics of mass balance; although the mass balance of different sites may vary for a given year (as shown by the different means), their variations with time are similar for all locations. Lliboutry (1974) expressed the annual mass-balance $b_{\mathrm{i}, \mathrm{t}}$ in three terms:

$$
b_{\mathrm{i}, \mathrm{t}}=\alpha_{\mathrm{i}}+\beta_{\mathrm{t}}+\epsilon_{\mathrm{i}, \mathrm{t}},
$$

where $\alpha_{\mathrm{i}}$ is a time-independent term, reflecting the physical characteristics of the area surrounding the stakes (elevation, 
exposition). This is the mean mass balance at each stake over the period. $\beta_{\mathrm{t}}$ is time-dependent only and is calculated as the temporal average of the deviations from the mean at each stake. It represents the common signal of different sites and, in fact, the climate fluctuations (time average of zero). $\epsilon_{\mathrm{i}, \mathrm{t}}$ is a centred random error reflecting the difference between the ground reality, $b_{\mathrm{i}, \mathrm{t}}$, and the model. This model, its interests, extensions and limits are discussed in Lliboutry (1974), Reynaud (1980), Kuhn (1984), Letréguilly (1984) and Vallon and others (1998).

Thanks to this local-scale analysis, annual stake variations at each glacier are first compared and a unique temporal mass-balance series can be determined if the linear variation of mass balance with time can be assumed on the glacier.

\subsection{Large-scale methods}

Having dealt with the analysis of the individual sites, we now turn to a larger-scale analysis, comparing the variations of series of different sites in the accumulation and ablation zones, in order to determine the degree of consistency between annual mass-balance variations. However, this requires a complete dataset, i.e. a rectangular table of sites for which mass-balance values exist for every year of the period under study. Figure 2 shows that we are very far from this situation: the table contains more empty cells than filled ones. As a consequence, the original dataset was divided into a number of complete rectangular subsets.

The sites were compared by correlation or principalcomponent analysis (PCA). Correlation can be used to compare a pair of series. When more than two series are involved, PCA must be used. This method is very useful for evaluating similarities between the series, because it provides not only a statistical analysis of the whole dataset variance, but also a simple visual representation of how similar or different the series are. When the first two components are plotted against each other, each series is symbolized as a point. The percentage of the total variance explained by the first component reflects the degree of similarity between the series in the dataset. The other components may help in identifying the causes of the series differences.

\section{LOGAL-SGALE ANALYSIS}

The local-scale methods described above are now used to compare available data and to derive a unique series on each site.

\subsection{Accumulation area: direct comparison of different series on the same site}

The sites where different series exist and for which a direct comparison of the annual mass balance is possible are (see Fig. 2): Site 2 in the north, and T61 (Dépôt 420), T53 (JarlJoset), T41 (Crête), T31 (Station Centrale), T15 (Milcent) and T4 (Carrefour) in the centre (EGIG line). At Summit, the various drilling locations are spread over distances of up to $30 \mathrm{~km}$, so they cannot be regarded as originating from the same site. Summit data are analyzed in section 5 .

At Site 2 (altitude $1700 \mathrm{~m}$ ), two series exist (Bader, 1955; Benson, 1962), with 22 measurement years in common between 1933 and 1954. The annual layers were identified by the stratigraphic method in both ice cores. Surprisingly, the two series are not correlated $(R=0.04)$. In the Bader series, the mean and standard deviation are 40 and $10 \mathrm{~cm}$,
Table 1. Correlation coefficient ( $R$ ) between pairs of series for six sites along the EGIG line

\begin{tabular}{|c|c|c|c|c|}
\hline Site & Pair of series & Period & Method & $R$ \\
\hline \multirow[t]{2}{*}{ Carrefour } & $\begin{array}{l}\text { Pourchet (unp.) } \\
\text { Ambach (1970) }\end{array}$ & $\begin{array}{l}1959-67 \\
(9 \text { years })\end{array}$ & $\begin{array}{l}\text { strati } \\
\text { isotopic }\end{array}$ & 0.06 \\
\hline & $\begin{array}{l}\text { Ambach (1970) } \\
\text { Benson (1962) }\end{array}$ & $\begin{array}{l}1951-55 \\
(5 \text { years })\end{array}$ & $\begin{array}{l}\text { isotopic } \\
\text { strati }\end{array}$ & 0.44 \\
\hline \multirow[t]{3}{*}{ Milcent } & $\begin{array}{l}\text { Pourchet (unp.) } \\
\text { Dansgaard (1975) }\end{array}$ & $\begin{array}{l}1959-67 \\
(9 \text { years })\end{array}$ & $\begin{array}{l}\text { strati } \\
\text { isotopic }\end{array}$ & 0.79 \\
\hline & $\begin{array}{l}\text { Dansgaard (1975) } \\
\text { Benson (1962) }\end{array}$ & $\begin{array}{l}1951-55 \\
(5 \text { years })\end{array}$ & $\begin{array}{l}\text { isotopic } \\
\text { strati }\end{array}$ & -0.38 \\
\hline & $\begin{array}{l}\text { Dansgaard (1975) } \\
\text { de Quervain (1969) }\end{array}$ & $\begin{array}{l}1956-60 \\
(5 \text { years })\end{array}$ & $\begin{array}{l}\text { isotopic } \\
\text { strati }\end{array}$ & 0.35 \\
\hline \multirow[t]{3}{*}{$\begin{array}{l}\text { Station } \\
\text { Centrale }\end{array}$} & $\begin{array}{l}\text { Pourchet (unp.) } \\
\text { de Quervain (1969) }\end{array}$ & $\begin{array}{l}1948-60 \\
(13 \text { years })\end{array}$ & $\begin{array}{l}\text { strati } \\
\text { strati }\end{array}$ & 0.74 \\
\hline & $\begin{array}{l}\text { Pourchet (unp.) } \\
\text { Benson (1962) }\end{array}$ & $\begin{array}{l}1947-55 \\
(9 \text { years })\end{array}$ & $\begin{array}{l}\text { strati } \\
\text { strati }\end{array}$ & 0.48 \\
\hline & $\begin{array}{l}\text { de Quervain (1969) } \\
\text { Benson (1962) }\end{array}$ & $\begin{array}{l}1948-55 \\
\text { (8 years) }\end{array}$ & $\begin{array}{l}\text { strati } \\
\text { strati }\end{array}$ & 0.50 \\
\hline \multirow[t]{3}{*}{ Crête } & $\begin{array}{l}\text { Pourchet (unp.) } \\
\text { Clausen (1988) }\end{array}$ & $\begin{array}{l}1954-68 \\
(15 \text { years })\end{array}$ & $\begin{array}{l}\text { strati } \\
\text { isotopic }\end{array}$ & 0.65 \\
\hline & $\begin{array}{l}\text { Pourchet (unp.) } \\
\text { de Quervain (1969) }\end{array}$ & $\begin{array}{l}1954-60 \\
(7 \text { years })\end{array}$ & $\begin{array}{l}\text { strati } \\
\text { strati }\end{array}$ & 0.49 \\
\hline & $\begin{array}{l}\text { de Quervain (1969) } \\
\text { Clausen (1988) }\end{array}$ & $\begin{array}{l}1952-60 \\
(9 \text { years })\end{array}$ & $\begin{array}{l}\text { strati } \\
\text { isotopic }\end{array}$ & 0.04 \\
\hline Jarl-Joset & $\begin{array}{l}\text { Pourchet (unp.) } \\
\text { de Quervain (1969) }\end{array}$ & $\begin{array}{l}1953-60 \\
(8 \text { years })\end{array}$ & $\begin{array}{l}\text { strati } \\
\text { strati }\end{array}$ & 0.91 \\
\hline Dépôt 420 & $\begin{array}{l}\text { Pourchet (unp.) } \\
\text { de Quervain (1969) }\end{array}$ & $\begin{array}{l}(1953-59) \\
(7 \text { years })\end{array}$ & $\begin{array}{l}\text { strati } \\
\text { strati }\end{array}$ & 0.32 \\
\hline
\end{tabular}

Notes: Bold numbers indicate significant coefficients at the $5 \%$ level of confidence. strati, stratigraphic method.

respectively, while they are only 21 and $4 \mathrm{~cm}$ in the Benson series for the same period.

The sites on the EGIG line where direct comparisons are possible have been correlated in pairs for their common periods (Table 1). The correlation coefficients are significant (at the $5 \%$ level) for a few pairs of series, but not for most, as shown by the three series from Carrefour station (Benson, 1962; Ambach and Dansgaard, 1970; Pourchet, unpublished). The patterns are the same for the other stations (Station Centrale, Milcent and Crête).

The results of comparisons of annual accumulation series obtained from the same sites are surprisingly poor; it would seem that in most cases a data series obtained from one ice core is not reproducible by another. As a consequence, even for a significant correlation, it did not seem justifiable to set up mean accumulation series with the different series available for each site.

\subsection{Ablation area: comparisons of stake data}

Annual mass balances vs altitude are available in the literature for five glaciers: Nordbogletscher, Qamanârssûp sermia, 1CE05025, 1CG14033 and Russel (now called the Ktransect). An example of a comparison of yearly stake fluctuations is presented below along the K-transect. 


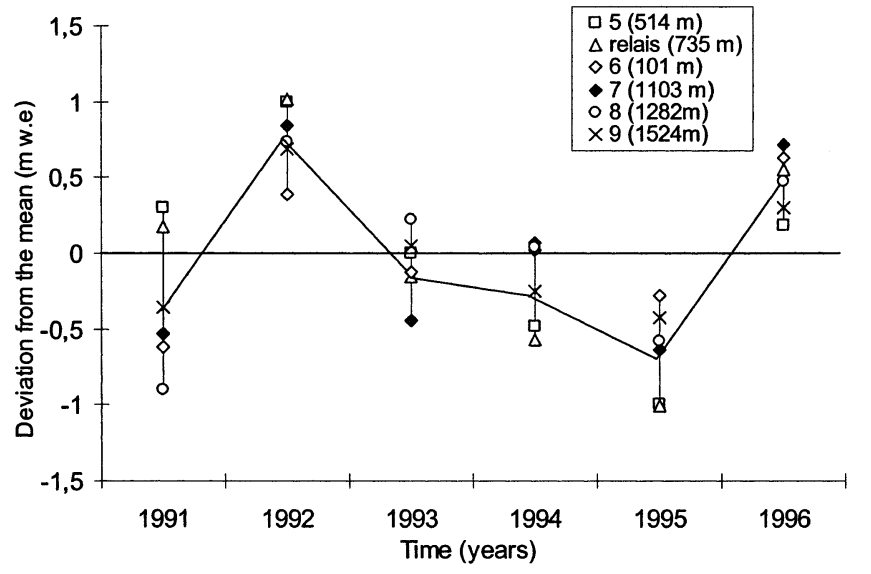

Fig. 3. Mass-balance deviations from the means $\left(\beta_{\mathrm{t}}\right)$ vs time for six stakes along the K-transect (in $m$ w.e). The legends give the site number and altitude $(\mathrm{m})$. Data from Van de Wal and others (1996) and Greuell and Knap (2000).

K-transect

The mass-balance series vs altitude for this glacier are provided by Van de Wal and others (1996) and Greuell and Knap (2000) for the period 1990-96 (complete on six stakes). Comparisons between stakes were made using annual deviations from the mean. These deviations are plotted vs time in Figure 3. A common temporal signal can be seen for all stakes. With $75 \%$ covariance of the mass-balance series explained, the linear model of variations can be assumed to be a good approximation. On this glacier, a unique temporal series $\left(\beta_{\mathrm{t}}\right.$ term $)$ could be deduced using the linear algorithm of Lliboutry (1974). This result is important, considering the large elevation range of the stakes (almost $1000 \mathrm{~m}$ ). Figure 3 also shows that there is an important interannual variability along the K-transect, close to $1 \mathrm{~m}$ w.e.

\section{Other glaciers}

A similar technique was applied to other glaciers for which mass-balance vs altitude data are available. As such series are often incomplete, we analyzed the deviations from the mean at each stake on reduced datasets. Analysis of these glaciers led to results similar to those from the K-transect, i.e. there is a common signal between all stakes of a particular glacier $(70-80 \%$ of common variance), and interannual variability of up to $1.5 \mathrm{~m}$ w.e. can be observed. This variability is not far from that observed in very different glacier environments, such as in the Alps, where it approaches $2 \mathrm{~m}$ (Reynaud, 1980).

For all these glaciers, the linearity assumption was therefore justified to derive a unique temporal series. The sites for which the linear model was used are: Qamanârssûp sermia, Nordbogletscher, K-transect, 1CE05025 and 1CG14033 glaciers (Table 2). These sites (except 1CG14033 glacier) are outlet glaciers of the ice sheet. For glaciers Qapiarfiup and Vahaltinde, the authors have calculated the global massbalance values, so unique series are already available. For Paakitsup glacier, the $\beta_{\mathrm{t}}$ series is the one given by Braithwaite and others (1992), who used the same method as that used here (stake data not available).

\section{LARGE-SGALE ANALYSIS}

In order to check for regional consistency of mass-balance variations on larger scales than those of one site or one glacier, comparisons can be made between different sites: glaciers in the ablation area; cores or pits in the accumulation area. The method used to analyze the mass balance on the different stakes along the K-transect (i.e. deviations from the mean) can now be applied to compare different glaciers in the ablation area or different cores or pits in the accumulation area, using series covering common time periods. In the ablation area, we first used the subsets involving neighbouring glaciers, then enlarged the analysis to more distant sites. In the accumulation area, the largest number of sites is first presented, then different parts of this area are detailed.

\subsection{Southwest region (ablation area)}

The analysis of this zone is based on the data in Table 2,

Table 2. Mass-balance deviations from the means $\left(\beta_{\mathrm{t}}\right)$ of eight glaciers on the southwest coast (in $m$ w.e)

\begin{tabular}{|c|c|c|c|c|c|c|c|c|}
\hline Tear & $K$-trans & ICE05 & Paaquit & $1 C G 14$ & Qamân & Qapiar & Nordbo & Vahal \\
\hline 1978 & & & & & \multirow{4}{*}{$\begin{array}{c}0.20 \\
-0.22\end{array}$} & \multirow[b]{4}{*}{-0.02} & \multicolumn{2}{|l|}{-0.27} \\
\hline 1979 & & & & & & & 0.32 & 0.16 \\
\hline 1980 & & & & & & & -0.61 & -0.06 \\
\hline 1981 & & & & & & & -0.30 & -0.34 \\
\hline 1982 & & & & -0.03 & \multirow{3}{*}{$\begin{array}{c}-0.03 \\
0.85 \\
0.64 \\
-0.66\end{array}$} & \multirow{3}{*}{$\begin{array}{c}-0.21 \\
0.71 \\
0.49 \\
-0.79\end{array}$} & -0.02 & -0.11 \\
\hline 1984 & & -0.08 & 0.01 & 0.18 & & & & \\
\hline 1985 & & -0.16 & -0.56 & -0.94 & & & & \\
\hline 1986 & & 0.19 & 0.45 & 0.15 & -0.13 & & & \\
\hline 1987 & & -0.16 & -0.48 & -0.28 & -0.65 & & & \\
\hline 1988 & & 0.22 & -0.35 & 0.22 & & & & \\
\hline 1989 & & & 0.13 & & & & & \\
\hline 1990 & & & & & & & & \\
\hline 1992 & 0.83 & & & & & & & \\
\hline 1993 & -0.02 & & & & & & & \\
\hline 1994 & -0.19 & & & & & & & \\
\hline 1995 & -0.70 & & & & & & & \\
\hline 1996 & 0.32 & & & & & & & \\
\hline
\end{tabular}

Notes: These values are calculated as the first step of the linear variation model of Lliboutry (1974) from mass-balance vs altitude data available in the literature, except for Paakitsup glacier for which $\beta_{\mathrm{t}}$ is taken from Braithwaite and others (1992). The thick lines represent the different subsets analyzed. K-trans, K-transect; 1CE05, 1CE05025; Paaquit, Paakitsup; 1CG14, 1CG14033; Qamân, Qamanârssûp; Qapiar, Qapiarfiup; Vahal, Vahaltinde. 

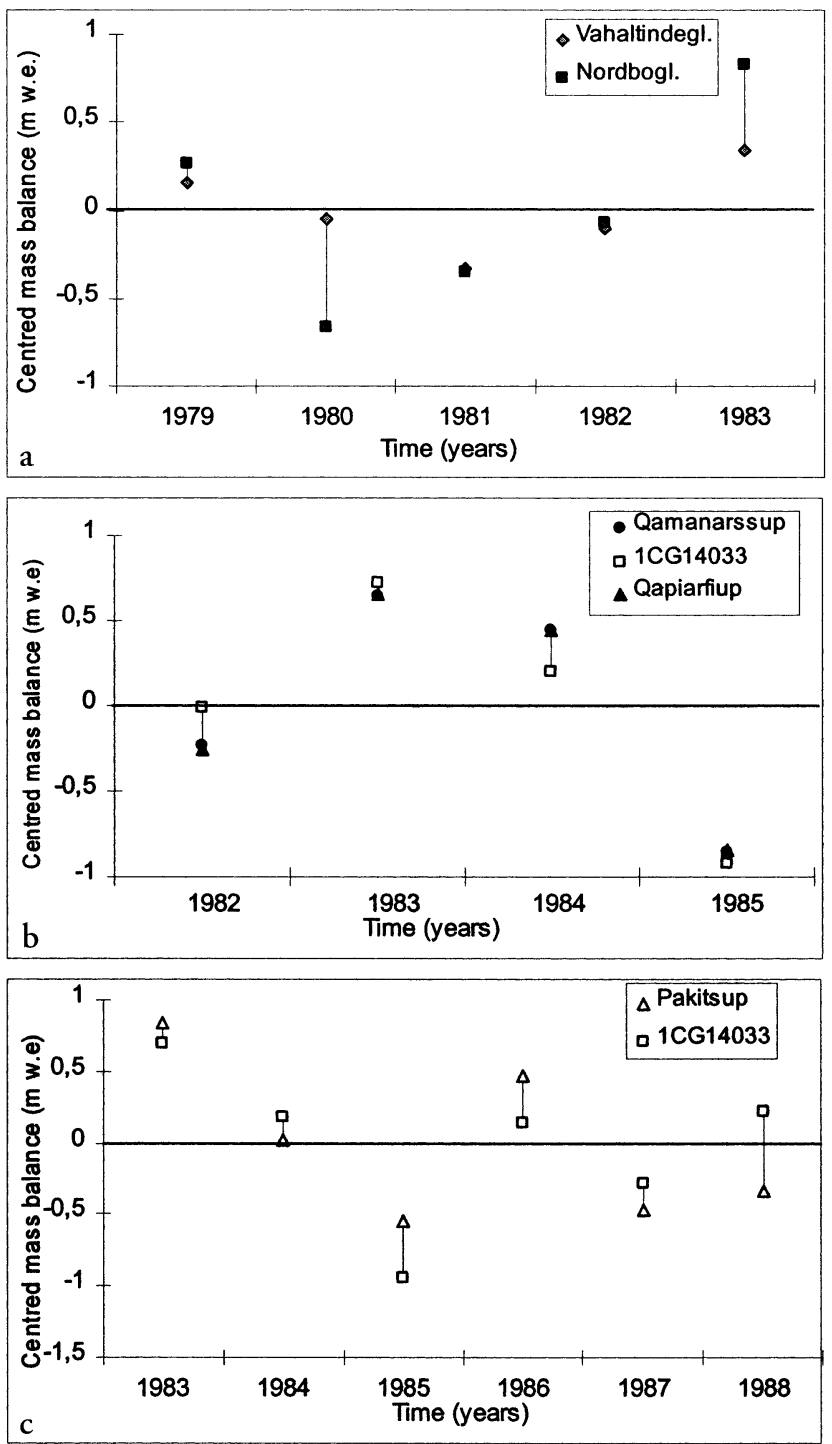

Fig. 4. Deviations from the means ( $\beta_{\mathrm{it}}$, in mw.e.) vs time for three different subsets of mass-balance series of the southwestern ablation zone (data from Table 3): (a) two neighbouring glaciers (about $5 \mathrm{~km}$ apart), Vahaltindegletscher and Nordbogletscher (data from Haeberli and Müller (1988) and Braithwaite (1985), respectively); (b) Qamanârssûp sermia, Qapiarfiup sermia and 1CG14033 glacier, located $200 \mathrm{~km}$ apart (data from Braithwaite (1989), Haeberli and Müller (1988) and Braithwaite (1990), respectively); (c) Paakitsup and 1CG14033 glaciers, located $600 \mathrm{~km}$ apart (data from Braithwaite and others (1992) and Braithwaite (1990), respectively).

which also shows some of the different subsets that can be analyzed.

Figure 4 shows the deviations from the mean for three different subsets, covering very different areas of the southwestern ablation zone. The first includes two southern neighbouring glaciers, Nordboglestcher and Vahaltindegletscher, which are only $5 \mathrm{~km}$ apart. The second set includes three glaciers (Qamanârssûp, Qapiarfiup and 1CG14033) located $200 \mathrm{~km}$ apart, and the third includes Paakitsup and 1CG14033 located $600 \mathrm{~km}$ apart.

Despite the very different distances covered by the datasets, the results are the same for all the analyzed subsets; the deviations from the means are very similar and the spatial scale of consistency between yearly variations observed here is of the same order as that previously observed in
Table 3. First factor of a PCA performed on different subsets of the centre of Greenland

\begin{tabular}{|c|c|c|c|c|c|}
\hline \multirow[t]{2}{*}{ Subset } & Source & Sites & Distance & Period & First factor \\
\hline & & & $\mathrm{km}$ & & $\%$ \\
\hline
\end{tabular}

All the EGIG line

$\begin{array}{llllll}1 & \text { Am, P } & \text { Ca, M, SC, Cr, JJ } & 680 & 1959-68 & 39.3 \\ & & & \\ & \text { D420, D480 } & & & \\ & \text { T5, T9, T13, T17, } & 460 & 1983-89 & 74.3 \\ & \text { T21, T27, SC, } & & & \\ & \text { T41, Cr, S } & & \end{array}$

Western part of EGIG line

\begin{tabular}{|c|c|c|c|c|c|}
\hline 3 & $\mathrm{Be}$ & $\begin{array}{l}\mathrm{Ca}, \mathrm{T} 5, \mathrm{~T} 9, \mathrm{~T} 13, \\
\mathrm{M}, \mathrm{T} 21, \mathrm{~T} 27, \mathrm{SC}\end{array}$ & 300 & $1951-55$ & 60.5 \\
\hline 4 & Am, $\mathrm{P}$ & $\mathrm{Ca}, \mathrm{T} 15, \mathrm{SC}$ & 300 & $1959-67$ & 68.1 \\
\hline 5 & An & $\begin{array}{l}\text { T5, T9, T13, T17, } \\
\text { T21,T27, SC }\end{array}$ & 260 & 1983-89 & 85 \\
\hline 6 & Am, D, P & $\mathrm{Ca}, \mathrm{M}, \mathrm{SC}$ & 300 & $1949-67$ & 47.3 \\
\hline \multicolumn{6}{|c|}{ Central part, Crête and Summit areas } \\
\hline 7 & $\mathrm{Cl}$ & $\begin{array}{l}\text { Cr, A, B, C, D, E, } \\
\text { F, G, H, Cr, S }\end{array}$ & 180 & $1943-73$ & 56 \\
\hline 8 & Bo, $\mathrm{Al}, \mathrm{L}$ & $\begin{array}{l}\text { p. GISP2, GISP2, } \\
\text { L }\end{array}$ & 30 & $1953-72$ & 46.2 \\
\hline 9 & $\mathrm{An}, \mathrm{Bo}, \mathrm{Al}$ & $\begin{array}{l}\text { An, p. GISP2, } \\
\text { GISP2 }\end{array}$ & 30 & $1970-86$ & 57 \\
\hline 10 & Bo & $\begin{array}{l}8 \text { sites around } \\
\text { Summit }\end{array}$ & 130 & $1964-88$ & 33.4 \\
\hline 11 & An & T41, Cr, S & 210 & 1979-89 & 76.5 \\
\hline \multicolumn{6}{|c|}{ Eastern part } \\
\hline 12 & $\mathrm{P}$ & JJ, D420, D480 & 180 & $1957-68$ & 58.7 \\
\hline 13 & de $Q$ & JJ, D420 & 70 & $1953-59$ & (75) \\
\hline
\end{tabular}

Notes: Distance (column 4) is the approximate distance separating the sites most distant from each other in the set. The value of set 13 in parentheses gives the common variance between the series because a PCA on two series can be considered as an orthogonal correlation. Abbreviations used are: Authors: Al, Alley and others (1997); Am, Ambach and Dansgaard (1970); An, Anklin and others (1994); Be, Benson (1962); Bo, Bolzan and Strobel (1994); Cl, Clausen and others (1988); D, Dansgaard and others (1975); L, Langway and others (1985); P, Pourchet (unpublished); de Q de Quervain and others (1969). Sites: Ca, Carrefour (T4); M, Milcent (T15); SC, Station Centrale (T31); Cr, Crête (T43); Cr S, Crête Swiss; S, Summit; JJ, Jarl-Joset (T53); D420, Dépôt 420 (T61); D480, Dépôt 480 (T66); p. GISP2, part of the GISP2 campaign. When the site is unnamed, the letter represents the author (eg. L, Langway).

mountainous areas (e.g. Alps, Tien Shan), i.e. $600 \mathrm{~km}$ (Letréguilly, 1984; Cogley and Adams, 1998).

\subsection{Gentre of the accumulation area}

This area comprises the EGIG line across the inland ice, and the Crête and Summit regions $200 \mathrm{~km}$ north of it. As shown in Figure 2, possibilities for analysis are numerous. Table 3 summarizes the various sets analyzed. Analysis along the EGIG axis was divided into three parts: west, centre (including Crête and Summit data) and east.

\section{The entire EGIG line}

Along the EGIG line, expeditions by Benson (1962), Anklin and others (1994) and Pourchet (unpublished) provided annual data. Unfortunately, the data are neither for common periods nor for exactly the same set of sites. We started the analysis with three subsets corresponding to these three expeditions, with the largest possible number of sites (subsets 1-3, Table 3). In subset 1, the Ambach and Dansgaard (1970) series for Carrefour replaced that of 

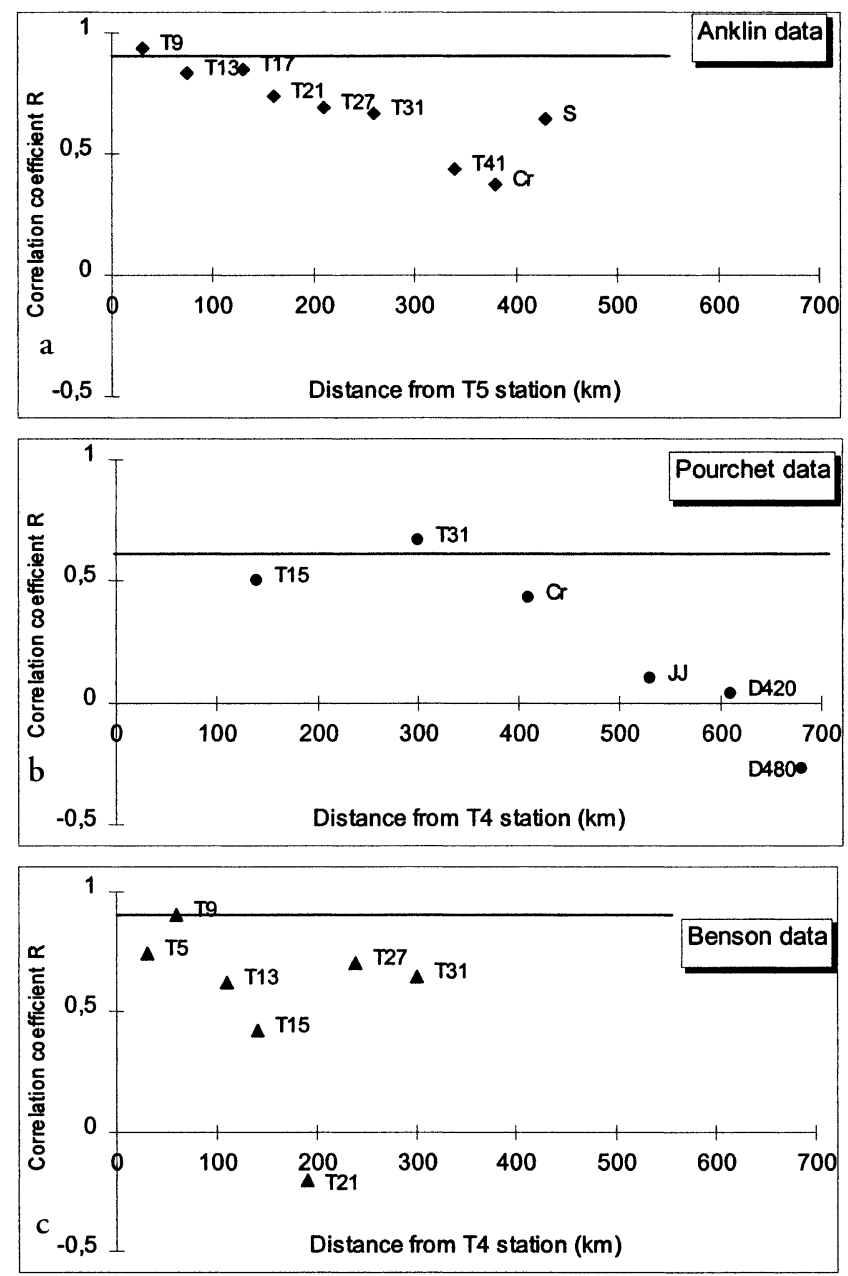

Fig. 5. Correlation coefficient $(R)$ between the westernmost site of each series and the other sites along the EGIG line, vs distance between the sites. (a) Dataset 1 (Anklin and others, 1994); (b) dataset 2 (Ambach and Dansgaard, 1970; Pourchet, unpublished); (c) dataset 3 (Benson, 1962). The horizontal lines represent the significance level (95\%) of the correlation coefficient. S, Summit; Cr, Crête; FF, Farl-Foset.

Pourchet because, according to Pourchet, his data were not reliable. For each set, Figure 5 presents the correlation coefficients $R$ between the westernmost site of each set and the other sites, vs distance between the sites. The correlation between neighbouring sites is high, generally decreasing with distance, and the correlation with sites from the central or eastern part of the EGIG line is usually not significant. Figure 6, showing the mean mass balance and standard deviation for each site, indicates that conditions on the inland ice change strongly between the edge of the accumulation area and the centre; on average, massbalance mean values are twice as high near the edge ( $50 \mathrm{~cm}$ w.e.) as near the centre $(25 \mathrm{~cm}$ w.e.), and the same patterns appear for the standard deviation of the mass balance $(10 \mathrm{~cm}$ vs $5 \mathrm{~cm}$ w.e. in the centre). Indeed, as noted by Radok and others (1982), Barlow and others (1997) and White and others (1997), the precipitation gradient is very pronounced because the ice sheet is an orographic barrier to precipitation.

For the Benson series (Benson, 1962) (subset 3), the way the values have been obtained (graph) has probably induced a smoothing effect on the variations and reduced the standard deviation. This may explain why we do not find the pattern observed in the other two datasets.
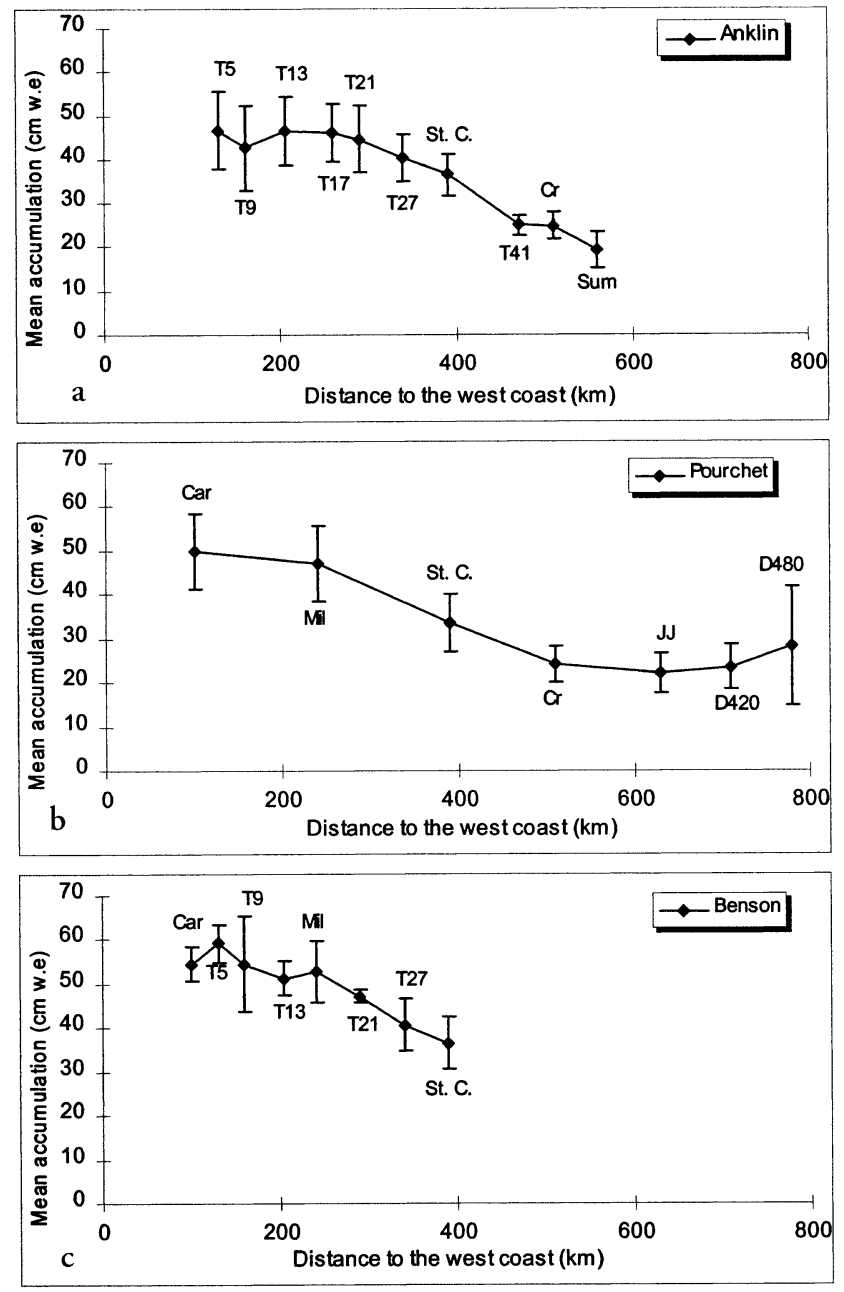

Fig. 6. Accumulation means and standard deviations vs distance to the west coast: (a) dataset 1 (Anklin and others, 1994); (b) dataset 2 (Ambach and Dansgaard, 1970; Pourchet, unpublished); (c) dataset 3 (Benson, 1962).

In the following, the sites have been grouped in smaller subsets (distances of around $300 \mathrm{~km}$, where some consistency in the variations can be expected), to detail the variations in the patterns (rest of Table 3).

\section{Western part of EGIG line}

Subsets 4 and 5 are the same expeditions as subsets 1 and 2, but confined to the western part. PCA applied to these subsets gives better results than for the larger sets 1 and 2. It indicates that a common interannual signal can be found, especially for set 5 . This can also be seen in Figure 7 which shows the deviations from the mean of the three western sets $3-5$; there is consistency in the year-to-year mass-balance fluctuations over a distance of about $300 \mathrm{~km}$.

For Carrefour, Milcent and Station Centrale, the accumulation series can be compared for a continuous period (194667) using the independently obtained data of Ambach and Dansgaard (1970), Dansgaard and others (1975) and Pourchet (unpublished) (subset 6). The first PCA factor is only $47 \%$, which is lower than for the previous sets, and in particular lower than subset 4 which covers the same area, with the same number of sites. This result agrees with those observed in Table 1 , for different series on the same site. Note that comparing different series originating from different work seldom leads to consistent results.

No particular accumulation change appears for these stations over the different periods studied (1951-55, 1959-68 and 

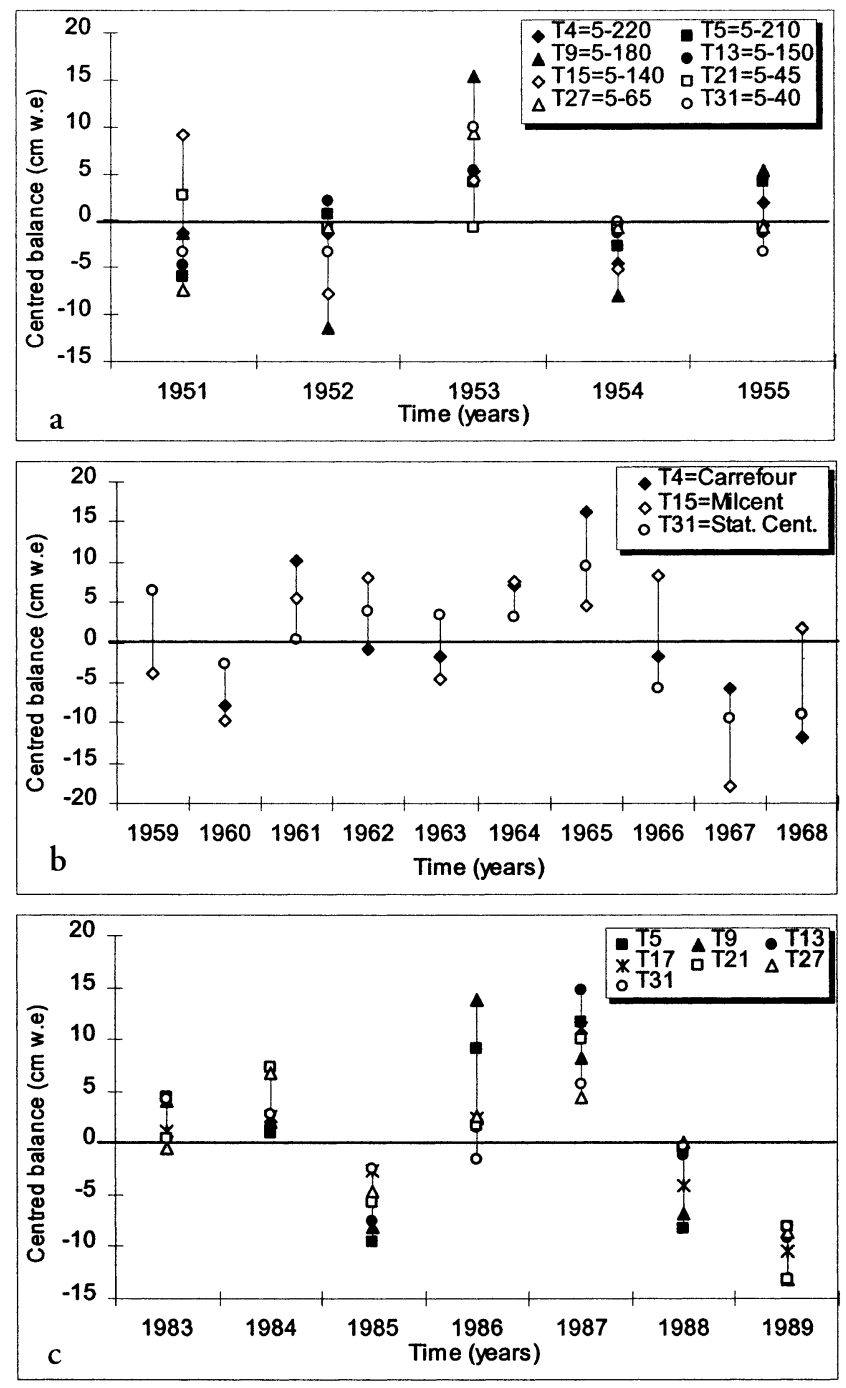

Fig. 7. Deviations from the means (in cm w.e.), on the western part of the EGIG line: (a) subset 3 (Benson, 1962); ( b ) subset 4 (Ambach and Dansgaard, 1970; Pourchet, unpublished); (c) subset 5 (Anklin and others, 1994).

1983-89). Even with older data covering the period 1911-31 at Milcent and Station Centrale (Diamond, 1956; Dansgaard and others, 1975), no significant change is observed. Mean

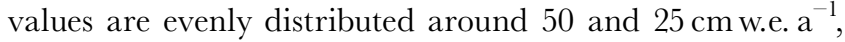
respectively. These results agree with the most recent analyses of Krabill and others (2000) and Thomas and others (2000) who conclude that the high-elevation area of the ice sheet shows no net change in ice volume.

\section{Central part, Crête and Summit areas}

In the central part of the ice sheet, some subsets consist of a group of series originating from the same work (e.g. the eight sites around Crête and Crête Swiss (subset 7; Clausen and others, 1988), the eight sites around Summit (subset 10; Bolzan and Strobel, 1994) or the most recent series (subset 11; Anklin and others, 1994)), while others, originating independently, have been grouped (subsets 8 and 9). However, all series come from an area measuring approximately $300 \mathrm{~km} \times 300 \mathrm{~km}$ on the top of the inland ice, with more or less the same physical and climatological characteristics. It was hence somewhat surprising to see the differences in the PCA results from one set to the other: from $77 \%$ (set 11) to $33 \%$ (set 10). The set with the highest PCA result is the one that covers the largest area.

The sets enclosing Summit station (sets 8 and 9) have a

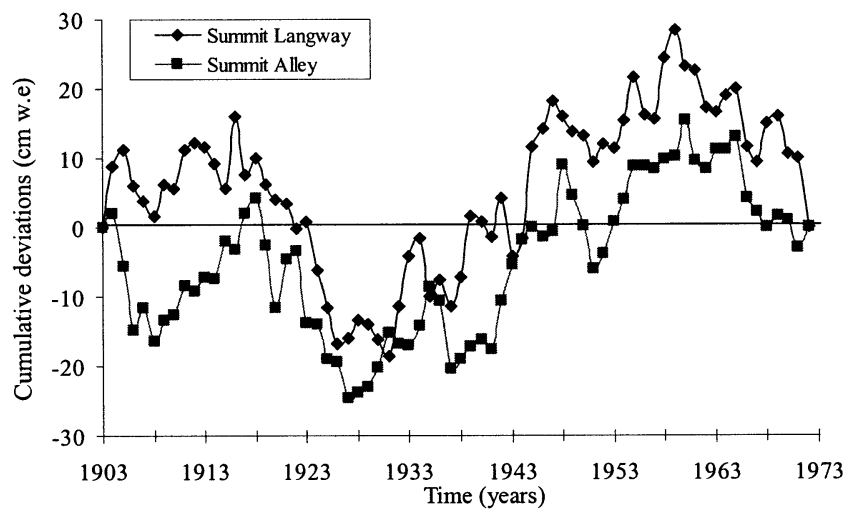

Fig. 8. Cumulative deviations from the means for massbalance series of Langway and others (1985) and Alley and others (1997) over their common period 1903-72 (in cm ice). The sum of annual $\beta_{\mathrm{t}}$ is useful for visualizing the main trends between the two signals. Although annual fluctuations do not match exactly, a global common trend can be observed for the two series. Annual correlation was, however, very poor between the two.

rather low PCA factor, and the correlation coefficients calculated over common periods are not significant (Table 4). However, average accumulation is the same for all sites (around $22 \mathrm{~cm}$ w.e. $\mathrm{a}^{-1}$ ). A plot of the cumulated deviations (Fig. 8) shows that common features can be found between the series of Langway and others (1985) and Alley and others (1997), although annual correlation is poor. This can also be seen for Crête station and its surroundings (subset 7, graph not shown here).

For sets $7-11$ it thus appears that the values averaged over a few years can produce reliable indications of real accumulation, but the single annual values cannot.

\section{Eastern part of EGIG line}

On the eastern part of the ice sheet, data are very sparse. The usable series are provided by M. Pourchet (unpublished) (subset 12), and by de Quervain and others (1969) (subset 13). The lower PCA result of set 12 is largely caused by D480, which has an unusually high variability.

\subsection{Northern part of the ice sheet}

In the north, six main expeditions provide long series: two on Site 2 (Bader, 1955; Benson, 1962), one on the nearby site of Camp Century (Nijampurkar and Clausen, 1990) (unfortunately there is no common period with Site 2), those of Humboldt and NASA-U (Anklin and others, 1998) and the

Table 4. Correlation coefficients ( $R$ ) between four accumulation series around Summit station (data from Langway and others, 1985; Anklin and others, 1994; Bolzan and Strobel, 1994; Alley and others, 1997)

\begin{tabular}{|c|c|c|c|c|}
\hline & Bolzan & Anklin & Langway & Alley \\
\hline Bolzan & 1 & $0.09(17)$ & $0.41(20)$ & $0.22(34)$ \\
\hline Anklin & & 1 & / (3) & $0.73(19)$ \\
\hline Langway & & & 1 & 0.35 (68) \\
\hline Alley & & & & 1 \\
\hline
\end{tabular}

Notes: Numbers in parentheses represent the common years between two series. The symbol / identifies common periods that are too short to be significant. The numbers in bold are significant at the $95 \%$ level. 


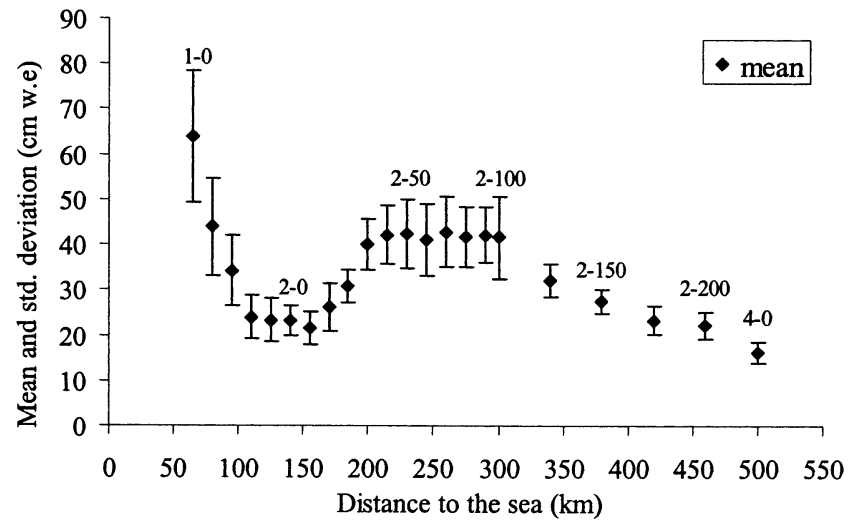

Fig. 9. Means and standard deviations of northern stations of the ice sheet for the period 1943-55, from 1-0 station to 4-0 station, as a function of the distance to the west coast. The large mean and standard deviation of Site 1 could be related to its proximity to the sea (about $90 \mathrm{~km}$ ), and the low values around Site 2 to the northward deviation of the traverse. Data from Benson (1962).

long traverse series of Benson (1962). The analysis performed in section 4 on the two Site 2 series showed no correlation. As would be expected considering the distances separating them, the Humboldt, NASA-U and Benson sites show no annual correlation. The Benson traverse is the only group in the north that has a sufficiently dense distribution to allow variance analysis. Figure 9 presents means and standard deviations for all stations from 1-0 to 4-0, including intermediate stations not shown in Figure 1 for the sake of clarity. As observed on the EGIG line, the interannual variability roughly decreases from the edge of the accumulation area to the centre. The low values observed around Site 2 are probably caused by the northerly deviation of the traverse, and the greater values at Site 1 by the proximity of the coast. Site 4 has the lowest mean and standard deviation observed in our work: 16.5 and $2.4 \mathrm{~cm}$ w.e., respectively.

The PCA results for various sections of the Benson traverse from Site 1 to Site 4 (northerly east-west section) and Site 4-0 to 5-0 (north-south central section) are reported in Table 5. The PCA results are in the same range as those previously observed in the other parts of the ice sheet.

\subsection{The entire ice sheet}

In the previous sections, mass-balance series have been analyzed within specific sectors of the ice sheet. However, comparisons of mass-balance variations on the scale of the entire ice sheet are also possible. Previously, we found that annual correlations between series from sites distant from each other are usually low, and this sometimes also applies to sites that are close together. However, using cumulated deviations, we found that main trends are sometimes comparable for different sites (e.g. Crête and surrounding sites, Summit sites). In this section, a triangular filter was applied to the long series of Figure 2 in order to remove high interannual variability and to enhance the main common trends between the sites (Milcent, Greenland Ice Sheet Project (GISP), Summit, Crête and NASA-U stations). Consistency was found for these five sites even though annual correlations were very poor. The interesting aspect of this treatment lies in the fact that mean values can provide valuable indications of global temporal trends over limited areas on the ice sheet.
Table 5. Results of the first component of a PCA for different subsets of the north traverse from 1-0 station to 4-0 station, and for the north-centre traverse from 4-0 to 5-0 (Benson, 1962). The periods under study are 1943-55 and 1946-55, respectively

\begin{tabular}{lll}
\hline Sites & $\begin{array}{c}\text { Maximal distance } \\
\mathrm{km}\end{array}$ & Factor 1 \\
& & \\
\hline 1-0 to $4-0(22$ sites $)$ & 450 & $57.7 \%$ \\
1-0 to $2-0(6$ sites $)$ & 100 & $52.5 \%$ \\
2-0 to $2-100$ & 120 & $75.9 \%$ \\
2-100 to $2-200$ & 160 & $57 \%$ \\
2-150 to $4-0$ & 140 & $53.3 \%$ \\
$4-0$ to $5-0$ & 700 & $49.3 \%$ \\
$4-0$ to $4-250$ & 400 & $39.6 \%$ \\
$4-250$ to $5-0$ & 300 & $73.9 \%$ \\
\hline
\end{tabular}

\section{DISCUSSION}

We have carried out a statistical analysis of the spatial and temporal variations of annual mass-balance series available in Greenland. Because of the poor spatial and temporal coverage of the series, the original dataset had to be split into a large number of smaller subsets. The results differ greatly according to the geographic area concerned, i.e. the ablation area or the accumulation area.

In the ablation area, the results are reasonably consistent and agree with those observed in other mountainous areas where such studies have been carried out. The deviations from the mean are relatively consistent from one site to another, even for sites up to about $600 \mathrm{~km}$ apart. The 30$40 \%$ of unexplained variance can be attributed partly to the spatial distribution of the natural climate, which is not the same all along the west coast, and partly to measurement inaccuracies related to the changing date of the end of the ablation season, the low number of stakes for the huge areas involved in Greenland, the uneven ice surface for reading the stakes, and the difficulties involved in making firn-density measurements. Unfortunately there is little information about these sources of error in the literature. Braithwaite and Olesen (1989) estimated a measurement error of around $20 \mathrm{~cm}$ w.e. under the best conditions, for stakes on Qamanârssûp glacier, which is in accordance with the values estimated for other mountainous areas (Cogley and Adams, 1998).

Interannual variability is relatively high in this region, up to $\pm 1 \mathrm{~m}$ with respect to the mean. Under these conditions, only long annual mass-balance series can produce reliable estimates of the mean mass balance on these glaciers. In the southwest ablation area, balance series are too short (never $>8$ years), and the results provide only a general indication of the real climate in the region under study.

In the accumulation area, the results are more varied. For some neighbouring sites (a few metres to a few kilometres apart), no correlation could be found, while for other subsets including series from more distant sites, statistical analysis shows consistent annual variations.

If we consider PCA results for the most consistent subsets of the accumulation area, we note that the distances involved are smaller than in the ablation area $(300 \mathrm{~km})$. Indeed, ablation is mostly linked to temperature, the annual variation of which is consistent over large distances, while accumu- 
lation is mostly linked to precipitation, which shows a higher spatial variability. This difference in the consistency distance between ablation and accumulation areas is also enhanced by the magnitude of their respective means and standard deviations, which are higher in the ablation area than in the accumulation area. In the accumulation area, means and standard deviations decrease from the edge to the centre, where they are not much higher than the measurement uncertainties, such as those caused by the surface roughness (sastrugis). In addition, the west and east sides of the ice sheet are subject to different maritime influences, the transition zone being the central region of the ice sheet around the divide. The transitional nature of the central zone, and the weak accumulation values probably explain why common variations of mass balance cannot be found in this region for distances of $>200 \mathrm{~km}$.

The low PCA results of the accumulation zone are more difficult to understand because in most cases the sets involved are in the same geographic location as other sets for which the PCA is higher. For example, subsets 8 (Crête and the eight neighbouring sites), 11 (eight sites around Summit) and 12 (T41, Crête and Summit) have a similar geographic location, but the results of the PCA vary from $77 \%$ to $33 \%$ (Table 3). According to Fisher and Koerner (1994) and White and others (1997), in cores within a few kilometres of each other, inter-core variance noise could be high due to areal irregularities in the snow-layer thickness of each layer. Under these conditions, the dating of ice cores by counting annual layers is subject to error. For instance, certain years may be missed due to the smoothing of annual signals by vapour diffusion in the firn. Other layers may entirely disappear because of an unusually strong melting event (as observed on one occasion by Bader (1955)) or because of local erosion by wind (according to Radok and others (1982), 60-70\% of the accumulation is the result of drifting and blowing snow). Moreover, combining several annual parameters (stratigraphy, conductivity or chemical elements) occasionally leads to discrepancies. A discrepancy of even lyear can strongly reduce a correlation coefficient which is based entirely on interannual variations.

For the Summit region, we tried to obtain a more detailed comparison by calculating the correlation coefficients of each of the pairs of series whenever a common period was available. It was found that the PCA score depends entirely on one particular pair, that of Anklin and Alley, and that the other correlations are not significantly different from 0 . When the cumulated deviations from the means of two uncorrelated series are compared (Fig. 8), similar variations appear, but they are not synchronous. This was also observed on other cumulated series at Crête or Milcent. Mean values therefore provide valuable indications of global temporal trends for limited areas on the ice sheet.

\section{CONGLUSION}

Despite the large number of mass-balance measurements on the Greenland ice sheet, only a limited number of series are well suited to statistical analysis. Furthermore, if we consider only those series giving consistent results, the number is reduced to just a dozen, and their variations are only partly comparable because of the different periods involved. Such series are essentially concentrated on the southwest edge and on a west-east profile in the centre of Greenland. For about two-thirds of the ice sheet, no usable data series is available for such an analysis.

However, the few usable series provide interesting results. In the ablation area, the interannual variations (reaching nearly $100 \mathrm{~cm}$ w.e. above or below the mean) are found to be consistent over a distance of $600 \mathrm{~km}$. In the accumulation area, where standard deviations vary from $10 \mathrm{~cm}$ w.e. near the edge to $5 \mathrm{~cm}$ w.e. in the centre, and mean values from 50 to $25 \mathrm{~cm}$ w.e., the distances over which consistency can be observed are somewhat smaller than in the ablation zone (400-200 km). However, given the very low values involved, it was remarkable to find any similarity at all.

The annual variability of mass balance compared to its mean value is not negligible. For sites in the accumulation area, the ratio of mean standard deviation to mean value is around $25 \%$, while in the ablation area it reaches $30-50 \%$. Estimating the mean mass balance on a site by means of a single annual measurement is therefore very hazardous, and the current estimations of the global mass balance of Greenland, which make use of all available measurements, are therefore rather uncertain, considering the highly variable geographic density and temporal disparity of the existing measurements. Only long series can provide valuable indications of the means and variations of the Greenland mass balance.

The reuse of existing measurement sites for future campaigns, as for example by Anklin (in accumulation area PARCA (Anklin and others, 1998)) or Braithwaite and Van de Wal (in the ablation area), would provide valuable information to detect possible changes. Furthermore, if the global mass balance of the ice sheet is to be established by means of field data, a much denser and more synchronous measurement network than the existing one will be required, with measurements performed every 200-400 km over long and comparable measurement periods.

\section{ACKNOWLEDGEMENTS}

We thank M. Pourchet, R. van de Wal and W. Greuell for providing unpublished data (at the time of the study) concerning the mass balance on the ice sheet, and M. Vallon, C. Vincent, C. Genthon and the anonymous referees for their valuable remarks. The scientific editor, D. Dahl-Jensen, helped bring the paper to its final form. This research was carried out in the framework of the European ICEMASS (ENV4-CT97-0490) contract with the financial support of the Ministère de la Recherche et de l'Enseignement Supérieur (MESR grant).

\section{REFERENCES}

Alley, R. B. and 11 others. 1997. Visual-stratigraphic dating of the GISP2 ice core: basis, reproducibility, and application. 7. Geophys. Res., 102(C12), 26,367-26,382.

Ambach, W. and W. Dansgaard. 1970. Fallout and climate studies on firn cores from Carrefour, Greenland. Earth Planet. Sci. Lett., 8, 311-316.

Anklin, M., B. Stauffer, K. Geis and D. Wagenbach. 1994. Pattern of annual snow accumulation along a West Greenland flow line: no significant change observed during recent decades. Tellus, 46B(4), 294-303.

Anklin, M., R. C. Bales, E. Mosley-Thompson and K. Steffen. 1998. Annual accumulation at two sites in northwest Greenland during recent centuries. 7. Geophys. Res., 103(D22), 28,775-28,783.

Bader, H., R.W. Waterhouse, J. K. Landauer, B. L. Hansen, J. A. Bender and T. R. Butkovich. 1955. Excavations and installations at SIPRE test site, Site 2, Greenland. SIPRE Rep. 20.

Barlow, L. K., J. C. Rogers, M. C. Serreze and R. G. Barry. 1997. Aspects of 
climate variability in the North Atlantic sector: discussion and relation to the Greenland Ice Sheet Project 2 high-resolution isotopic signal. $\mathcal{F}$. Geophys. Res., 102(C12), 26,333-26,344.

Bauer, A. 1955. The balance of the Greenland ice sheet. F. Glaciol., 2(17), 456-462.

Benson, C. S. 1962. Stratigraphic studies in the snow and firn of the Greenland ice sheet. SIPRE Res. Rep. 70.

Bolzan, J. F. and M. Strobel. 1994. Accumulation-rate variations around Summit, Greenland. 7. Glaciol., 40(134), 56-66.

Braithwaite, R. J. 1995. Relations between annual runoff and climate, Johan Dahl Land, south Greenland. Gronl. Geol. Undersogelse, Gletscher-Hydrologiske Meddelelser $85 / 2$.

Braithwaite, R. J. 1989. Glaciers and hydropower for Nuuk/Godthåb, West Greenland. Grønl. Geol. Undersøgelse, Open File Series 89/2.

Braithwaite, R. J. 1990. Seasonal runoff forecast for Kangerluarsunnguaq near Nuuk/Godthåb, West Greenland. Grønl. Geol. Undersøgelse, Open File Series $90 / 3$.

Braithwaite, R. J. 1996. Mass balance of the Greenland ice sheet: a century of progress but there is still much to do. Z. Gletscherkd. Glazialgeol., 31, Part $1,1995,51-56$.

Braithwaite, R. J. and O. B. Olesen. 1989. Detection of climate signal by interstake correlations of annual ablation data, Qamanârssûp sermia, West Greenland. f. Glaciol., 35(120), 253-259.

Braithwaite, R. J., O. B. Olesen and H. H. Thomsen. 1992. Calculated variations of annual ice ablation at the margin of the Greenland ice sheet, West Greenland, 1961-90. 7. Glaciol., 38(129), 266-272.

Glausen, H. B., N. S. Gundestrup, S. J. Johnsen, R. Bindschadler and J. Zwally. 1988. Glaciological investigations in the Crête area, central Greenland: a search for a new deep-drilling site. Ann. Glaciol., 10, 10-15.

Cogley, J. G. and W. P. Adams. 1998. Mass balance of glaciers other than the ice sheets. 7. Glaciol., 44(147), 315-325.

Dansgaard, W., S. J. Johnsen, N. Reeh, N. Gundestrup, H. B. Clausen and C. U. Hammer. 1975. Climatic changes, Norsemen and modern man. Nature, 255(5503), 24-28.

De Quervain, M., F. Brandenberger, O. Reinwarth, A. Renaud, A. Roch and R. Schneider. 1969. Schneekundliche Arbeiten der Internationalen glaziologischen Grönlandexpedition (Nivologie). Medd. Grønl., 177(4).

Diamond, M. 1956. Precipitation trends in Greenland during the past 30 years. SIPRE Res. Rep. 22.

Diamond, M. 1960. Air temperature and precipitation on the Greenland ice sheet. F. Glaciol., 3 (27), 558-567.

Fisher, D. A. and R. M. Koerner. 1994. Signal and noise in four ice-core records from the Agassiz Ice Cap, Ellesmere Island, Canada: details of the last millennium for stable isotopes, melt and solid conductivity. Holocene, 4(2), 113-120.

Greuell, W. and W. H. Knap. 2000. Remote sensing of the albedo and detection of the slush line on the Greenland ice sheet. F. Geophys. Res., 105(D12), 15,567-15,576.

Haeberli, W. and P. Müller, comps. 1988. Fluctuations of glaciers 1980-1985 ( Vol. $V$ ). Wallingford, Oxon, IAHS Press; Nairobi, UNEP; Paris, UNESCO.

Hammer, C. U., K. K. Andersen, H. B. Clausen, D. Dahl-Jensen, C. S. Hvidberg and P. Iversen. 1997. The stratigraphic dating of the GRIP ice core. Copenhagen, University of Copenhagen. Niels Bohr Institute for Astronomy, Physics and Geophysics. Department of Geophysics.

Krabill, W. and 9 others. 2000. Greenland ice sheet: high-elevation balance and peripheral thinning. Science, $\mathbf{2 8 9}$ (5478), 428-430.

Kuhn, M. 1984. Mass budget imbalances as criterion for a climatic classifi- cation of glaciers. Geogr. Ann., 66A(3), 229-238.

Langway, C. C., Jr, H. Oeschger and W. Dansgaard. 1985. Greenland ice core: geophysics, geochemistry, and the environment. Washington, DC, American Geophysical Union. (Geophysical Monograph 33.)

Letréguilly, A. 1984. Bilans de masse des glaciers alpins: méthode de mesure et répartition spatio-temporelle. (Thèse de 3ème cycle, Laboratoire de Glaciologie du GNRS et Université Joseph Fourier, Grenoble.) (Publ. 439.)

Letréguilly, A. and L. Reynaud. 1990. Space and time distribution of glacier mass-balance in the Northern Hemisphere. Arct. Alp. Res., 22(1), 43-50.

Lliboutry, L. 1974. Multivariate statistical analysis of glacier annual balances. 7. Glaciol., 13(69), 371-392.

Loewe, F. 1936. Höhenverhältnisse und Massenhaushalt des grönländischen Inlandeises. Gerlands Beiträge zur Geophysik, 46 (3), 317-330; 48(1), 86-89.

Mock, S. J. 1967. Accumulation patterns on the Greenland ice sheet. CRREL Res. Rep. 233.

Nijampurkar, V. N. and H. B. Clausen. 1990. A century old record of lead210 fallout on the Greenland ice sheet. Tellus, 42B, 29-38.

Oerlemans, J., R. S. van de Wal and L. A. Conrads. 1993. A model for the surface balance of ice masses. Part 2. Application to the Greenland ice sheet. Z. Gletscherkd. Glazialgeol., 27-28, 1991-1992, 85-96.

Ohmura, A. and N. Reeh. 1991. New precipitation and accumulation maps for Greenland. 7. Glaciol., 37(125), 140-148.

Ohmura, A., P. Calanca, M. Wild and M. Anklin. 1999. Precipitation, accumulation and mass balance of Greenland ice sheet. Z. Gletscherkd. Glazialgeol., 35(1), 1-20.

Pourchet, M. 1970. Repérage de niveaux radioactifs et mesure de l'accumulation sur l'axe EGIG (Groenland). Grenoble, Laboratoire de Glaciologie et Géophysique de l'Environnement. (Rapport interne.)

Radok, U., R. G. Barry, D. Jenssen, R. A. Keen, G. N. Kiladis and B. McInnes. 1982. Climatic and physical characteristics of the Greenland ice sheet. Part I and II. Boulder, CO, University of Colorado. Cooperative Institute for Research in Environmental Sciences.

Reeh, N. 1989. Dynamic and climate history of the Greenland ice sheet. In Fulton, R.J., ed. Quaternary geology of Canada and Greenland. Geology of Canada 1. Ottawa, Ont., Geological Survey of Canada; Boulder, CO, Geological Society of America, 794-822. (The Geology of North America K-1.)

Reynaud, L. 1980. Can the linear balance model be extended to the whole Alps? International Association of Hydrological Sciences Publication 126 (Riederalp Workshop 1978 - World Glacier Inventory), 273-284.

Reynaud, L., M. Vallon, S. Martin and A. Letréguilly. 1984. Spatio-temporal distribution of the glacial mass balance in the Alpine, Scandinavian and Tien Shan areas. Geogr. Ann., 66A(3), 239-247.

Thomas, R. and 6 others. 2000. Mass balance of the Greenland ice sheet at high elevations. Science, 289(5478), 426-428.

Vallon, M., C. Vincent and L. Reynaud. 1998. Altitudinal gradient of massbalance sensitivity to climatic change from 18 years of observations on glacier d'Argentière, France. f. Glaciol., 44(146), 93-96.

Van de Wal, R. S. and 11 others. 1996. Mass balance measurements in the Søndre Strømfjord area in the period 1990-1994. Z. Gletscherkd. Glazialgeol., 31, Part 1, 1995, 57-63.

Weidick, A. 1968. Observations on some Holocene glacier fluctuations in West Greenland. Medd. Gronl., 165(6).

White, J.W. C. and 7 others. 1997. The climate signal in the stable isotopes of snow from Summit, Greenland: results of comparisons with modern climate observations. 7. Geophys. Res., 102(C12), 26,425-26,439. 